\title{
Attitudes of Experts from Novi Sad on the Use of the Authentic Setting of the Petrovaradin Fortress as the Venue for the EXIT Festival
}

\author{
Besermenji Snežana ${ }^{A *}$, Pivac TatjanaA, Wallrabenstein Ksenija ${ }^{A}$ \\ Received: April 2010 | Revised: August 2010 | Accepted: August 2010
}

\begin{abstract}
The EXIT festival is one of the biggest cultural and social projects running in Serbia based on the concept of modern European festivals. The festival takes place on the Petrovaradin Fortress, which is immovable cultural asset of extraordinary importance. It belongs to the category of unique cultural and historic fortification structures with distinctive architectural and artistic values, with special emphasis on its cultural history.

Former researchers and practice have showed that both the attendees and organisers are satisfied with the Fortress as the festival venue, conversely to the experts in the field who are attempting from the outset to highlight the negative impact of the festival upon this cultural asset with some of them advocating the relocation of the festival.

The aim of this paper is to establish the experts' views on the use of the Petrovaradin Fortress as the venue for the EXIT festival. For the purpose of this paper, sixty experts responded to a questionnaire made by the researchers. The results obtained will draw attention to attitudes and opinions of experts and will be useful in future planning and organisation of the festival.
\end{abstract}

Key words: EXIT festival, Petrovaradin Fortress, cultural heritage asset, Novi Sad

\section{Introduction}

The EXIT festival was established at the end of the twentieth century and operates as a consortium of non-government organizations and industrial companies. The festival was organized for the first time in 2000 at the local level, but in $200 \mathrm{I}$ it grew into one of the largest musical and cultural festivals in south-eastern Europe (Besermenji at al, 2009; Pivac et al, 2007).

The festival takes place at the Petrovaradin fortress which becomes the centre of youth, culture and art at the time of the festival. Each year, at the time of the EXIT festival the Fortress is transformed into the gathering point of cultural tourism in Serbia. The Petrovaradin Fortress, as a historic, architectural, art and tourism gem, has proven itself as an ideal place for the festival such as EXIT. In addition to the original atmosphere, felt by all of the visitors and participants of the fes- tival, the Fortress offers high-quality acoustics so that it is possible to have stages close to each other without sound clashing (Besermenji et al, 2009).

The Petrovaradin Fortress was built between I692 and I780. Its creator was Sébastien le Prestre, Marquis de Vauban, who was the Marshal of France, an architect and a writer at the time of Louis XIV. The Petrovaradin Fortress was based on his system, at the time when artillery was developing, and it was called the Gibraltar on the Danube (Marković, I996).

The Fortress was declared immovable cultural asset of special interest and belongs to the category of unique cultural and historic fortification structures, with outstanding architectural, art and setting features with a special importance in the cultural history. Recently, the Petrovaradin Fortress entered the procedure for its proclamation as a cultural monument of extraordinary im-

\footnotetext{
A Department of Geography, Tourism and Hotel Management, Faculty of Science, University of Novi Sad; Trg Dositeja Obradovića 3, 21000 Novi Sad; Serbia

* Corresponding author: Besermenji Snežana, e-mail: atena21000@yahoo.com
} 
portance, which is the crucial condition for being under UNESCO protection.

Today, the Petrovaradin Fortress is home to the Academy of Arts, the City Museum of Novi Sad, Historic Archives, Equestrian Club and Archery Club, a luxury Hotel Leopold, several restaurants with a view of Novi Sad, and there is a network of catacombs under the Fortress, which can be visited with the Guide Service. There are numerous art studios of famous Novi Sad artists which are open for visits (Besermenji et al, 2009). The Petrovaradin Fortress is the largest tourist attraction of Novi Sad and a must for every tourist visiting the city. The higher protection level of the Petrovaradin Fortress would induce more visitors, since it has been the case with the objects of cultural heritage on the UNESCO's World Heritage list (Wager, I995).

Some places have powerful symbolic features that produce a strong effect on destination image perception, and Petrovaradin Fortress is one of those places.

\section{Literature review}

Events are important tourism incentives and represent developed forms of tourism and marketing plan of numerous destinations. The role and impact of event planning in tourism is well recorded and has an increasing influence on the competitiveness of a destination. It has been only several decades since the term 'event tourism' became integrated in tourism and science (Getz, 2007). Depending on the event venue, we can divide events into those which take place constantly or occasionally at the same venue, events that always take place at different venues and those that occasionally take place at several venues. The events that simultaneously take place at different venues are sports events and are usually represented by final competitions after regional and continental competitions. Events which take place constantly and occasionally at the same venue are organized in city centres with a developed transport system and accommodation and catering facilities. These events are regularly part of the tourism offer. Events that always take place at different venues are usually of continental or worldwide proportions, and the venue is selected through a bid competition of the organisation responsible for the competition. The venue is usually given to those who offer the best terms and conditions for the organisation (Romelić, 2006).

The most common forms of event tourism are festivals. According to the definition of the International Festival Association, "a festival is a grand celebration which needs to have special and original character. Its repertoire has to be different from regular programmes, worldwide, and create special atmosphere, which, in addition to high quality performance and performers, needs to depict the setting where that performance was created, with its atmosphere and its cultural, theatrical or musical tradition" (Hamović, I963).

According to Cultural Festival Group (Association for Tourism and Leisure Education, 2003), the festivals (events) are important occasions for the society, family or an individual to express their identities, way of life, social relationships and feelings of belonging. As Getz said, festivals 'comprise a large number of different events, including sports events, concerts, recreation, presenting sponsor products and their selling, as well as educational programmes' (Getz, I997).

Community festivals and special events have grown rapidly in number throughout the world during the past decade. Local festivals are increasingly being used as instruments for promoting tourism and boosting the regional economy (Felsenstein and Fleischer, 2003; Chang, 2005; Lee, Lee \&Wicks, 2004). Also, festivals are travel attractions with unique features (Gursoy, Kim \& Uysal, 2004). Many studies related to festivals focus on: host community reactions (Fredline, Faulkner, 200o), hallmark and major events (Lee, 2000), economic impacts (Crompton, Lee \& Shuster, 200I), resident's attitudes and perceptions (Jeong, Faulkner, I996) and the percived crowding of a festival experience (Lee, Graefe, 2003). However, there are very few papers exploring the issue of cultural assets as venues of the festivals (Besermenji et al, 2009). The venue of the festival is important. Numerous buildings, historical homes, castles and industrial buildings are venues for various events and festivals with cultural heritage themes.

There is an international trend in using main events and festival as generators of tourism (Stokes, 2008). The festivals not only attract visitors to the venue, but can also contribute to the 'creation of a positive image of a destination, enhance the tourist experience and contribute to the length of their stay' (Baum and Hagen, I999).

Lately, there has been an increase in the number of festivals in small and medium sized cities (Hadžić, 2004). A very nice example of this is the city of Novi Sad, which has become an important tourism destination because of the EXIT festival.

\section{Methodology}

Present researches (Besermenji et al, 2009) have shown that the attendees are extremely satisfied with the Fortress as the EXIT festival venue. From the foundation days of the festival, there have 
been public appeals by the experts in the field highlighting the possible negative impacts of the impressive number of visitors $(\approx 40,000)$ and music festival equipment simultaneously present at the Fortress. Therefore, there are individual expert's who appeal to higher protection level for this cultural object, or to relocating the festival. Since the festival receives financial support from Republic, Provincial and city authorities, authorised bodies from those institutions esteem both opinions and attitudes of experts in cultural assets protection under their jurisdiction. There is a burning issue about the authorised bodies offering unbiased support to all stakeholders in the EXIT festival (organisers, attendees, experts in cultural assets protection and experts in tourism), thus avoiding any damages or prevent errors.

Due to all those issues, the establishing of the experts' opinions upon the Petrovaradin fortress as the EXIT festival venue emerged as the focus of the research. We were interested whether they all hold similar attitudes upon the Fortress being inappropriate venue for the festival or there is only the impression conveyed by individual actions in mass media. The main aim of the research is to identify the experts' points of view which are the most similar to those of attendees and organisers. Such knowledge may contribute to better and more constructive relationship between the stakeholders in the future not only in organisation procedure, but also in practical aspects of the festival.

The sample consists of sixty employees of the Institute for the Protection of Cultural Heritage of Vojvodina and the Institute for the Protection of Cultural Heritage of Novi Sad, comprising $40 \%$ of the total sample $(\mathrm{N}=24)$ and the employees of travel agencies in Novi $\mathrm{Sad}(\mathrm{N}=36)$, i.e. $60 \%$ of the 'expert' sample. The sample comprises the majority of employees in institutions for the protection of cultural heritage, the experts in tourism employed in travel agencies ( 15 agencies in Novi Sad) which are directly or indirectly related to the EXIT festival. The sample includes 35 people who attended the festival (58.3\%) and 25 people who never attended the EXIT festival (4I.7\%).

The instrument of the research employed here is a questionnaire made by the authors-researchers. The questionnaire consists of three parts. The first part has one question with four answer modalities to which experts reply by expressing their opinion of cultural impact of the EXIT festival for Novi Sad. The second part includes a set of four attitudes upon the Fortress as the festival venue for the respondents to answer using the form of a five-point Likert scale (I- completely disagree; 5 - completely agree). The attitudes in the questionnaire were: ATTITUDE I - The Petrovaradin fortress is an excellent venue for the EXIT festival;
ATTITUDE 2 - The area of the Petrovaradin fortress offers a unique experience to the attendees of the festival; ATTITUDE 3 - the EXIT festival should be relocated; ATTITUDE 4 - the EXIT festival would be equally attractive if relocated.

The third part of the questionnaire offered the possibility of one open-type question for the respondents to comment on the Fortress as the venue for the festival. The results obtained in the questionnaire were submitted for data entry and processing according to their characteristics $\left(\mathrm{x}^{2}\right.$ test, t-test, F-test) in SPSS I3 for Windows.

The questionnaire was conducted individually and anonymously and the respondents were given instructions prior to completing their questionnaires.

\section{Results}

With regard to the importance and the role of the EXIT festival in the culture of Novi Sad, the 'experts' express the following attitudes: only 4 respondents $(6.7 \%)$ think that this festival is completely insignificant and without any impact on the culture of Novi Sad, and the same percentage considers EXIT as being slightly important. There is a significantly larger group of those who think that EXIT has a moderate importance and role, $28.3 \%$ of the respondents $(\mathrm{N}=\mathrm{I} 7)$. Most of the respondents, 35 of them or $58.3 \%$, said that EXIT has an outstanding importance for the culture of Novi Sad. These differences have been proven statistically significant by the application of the $x^{2}$ test $\left(\mathrm{x}^{2}=43.067 ; \mathrm{df}=3\right.$; Sig. $\left.=0.000\right)$.

In the evaluation of the importance of the EXIT festival for the culture of Novi Sad, no significant differences were observed between the attitudes of the 'experts' who attended the festival and those who did not $\left(\mathrm{x}^{2}=4.34 \mathrm{I} ; \mathrm{df}=3 ;\right.$ Sig. $\left.=0.227\right)$. Furthermore, the place of employment (institute or travel agency) was not a significant factor in the evaluation $\left(\mathrm{x}^{2}=\mathrm{I} .8 \mathrm{I} 2 ; \mathrm{df}=3\right.$; Sig. $\left.=0.6 \mathrm{I} 2\right)$.

In the valuation of the offered statements, the 'expert' had the following attitudes (Table I).

The mean value of agreement with the attitudes (on the 5-point Likert scale), demonstrates a clear tendency to more moderate attitudes. The only attitude with a clearly positive tendency is the one about the special experience the attendees have during the festival. In addition to attendees (Besermenji et al., 2009), the experts, on average, agree with this statement, which was, to a certain extent, our initial hypothesis. However, it is observable that the experts on average feel indecisive upon other attitudes. Even though for the measurement of attitudes, especially covering similar topics, it might be expected that the answers do not fall within normal distribution, which is 
Table 1. The agreement with the offered statements

\begin{tabular}{|c|c|c|c|c|c|}
\hline \multicolumn{2}{|c|}{$\begin{array}{l}\text { Is the EXIT festival important for the } \\
\text { culture of Novi Sad }\end{array}$} & \multirow{2}{*}{$\begin{array}{ll}\text { Item } 1 & \\
& 1.00\end{array}$} & \multirow{2}{*}{$\begin{array}{l}\text { Item } 2 \\
3.25\end{array}$} & \multirow{2}{*}{$\begin{array}{l}\text { Item } 3 \\
5.00\end{array}$} & \multirow{2}{*}{$\begin{array}{l}\text { Item } 4 \\
4.50\end{array}$} \\
\hline Not at all important & Mean & & & & \\
\hline & N & 4 & 4 & 4 & 4 \\
\hline & Std. Deviation & .000 & 2.062 & .000 & .577 \\
\hline \multirow{3}{*}{$\begin{array}{l}\text { Somewhat } \\
\text { important }\end{array}$} & Mean & 1.75 & 3.75 & 4.50 & 4.00 \\
\hline & $N$ & 4 & 4 & 4 & 4 \\
\hline & Std. Deviation & .957 & .957 & 1.000 & 1.414 \\
\hline \multirow{3}{*}{ Importan } & Mean & 3.12 & 4.24 & 3.29 & 2.71 \\
\hline & $N$ & 17 & 17 & 17 & 17 \\
\hline & Std. Deviation & 1.409 & 1.200 & 1.448 & 1.312 \\
\hline \multirow{3}{*}{ Very important } & Mean & 3.49 & 4.49 & 2.83 & 2.80 \\
\hline & $\mathrm{N}$ & 35 & 35 & 35 & 35 \\
\hline & Std. Deviation & 1.422 & 1.067 & 1.524 & 1.549 \\
\hline \multirow{3}{*}{ Total } & Mean & 3.10 & 4.28 & 3.22 & 2.97 \\
\hline & N & 60 & 60 & 60 & 60 \\
\hline & Std. Deviation & 1.504 & 1.195 & 1.541 & 1.495 \\
\hline
\end{tabular}

not the case here. Thus, it may be concluded that there is moderate difference of experts' opinion. It is noticeable that those who judge the EXIT festival as completely insignificant or of minor significance for the culture of Novi Sad display extreme attitudes. Such differences between those who have low judgment of cultural importance of the EXIT festival for Novi Sad, and those who have high judgment are confirmed as statistically significant by F-test (One-Way ANOVA) with regard to ATITUDE I $(\mathrm{F}=5,449 ; \mathrm{df}=3$; Sig.=0,002 $)$ and ATTITUDE 3 (F=3,989; df=3; Sig.=0,oI2).

Since there is a small share of those displaying extreme attitudes, we may conclude that such attitudes (mainly broadcasted in mass media) do not reflect the attitudes of the majority of experts since they are only individual actions and opinions broadcasted in mass media.

Yet, it needs to be emphasized that there are significant differences among the experts, concerning the evaluation of the attitudes, based on the fact whether they attended the festival or not.

The first attitude is agreed upon by those who attended the festival $(\mathrm{M}=3.37)$, whereas those who did not visit EXIT agree with the attitude to a lesser extent $(\mathrm{M}=\mathbf{2 . 7 2})$. The difference is not proven as statistically significant (by the application of the t-test); $(\mathrm{t}=\mathrm{I} .68 \mathrm{o} ; \mathrm{df}=58$; Sig.=0.098). In comparison to other statements, there are statistically significant differences. The second attitude is agreed upon by the 'experts' who attended the festival $(\mathrm{M}=4.57)$, unlike those who $\operatorname{did} \operatorname{not}(\mathrm{M}=3.88)$; $(\mathrm{t}=2.288 ; \mathrm{df}=58$; Sig.=0.026).

The third statement (about the relocation of the festival) is agreed upon mostly by the 'experts' who did not visit the festival $(\mathrm{M}=3.72)$, whereas those who attended it, agree with the statement and the idea to a smaller extent, on average (2.86); $(\mathrm{t}=-2.207 ; \mathrm{df}=58$; Sig.=0.03I). Those who attended the festival agree to a smaller extent with the statement that the EXIT would be equally attractive if organized in a different location $(\mathrm{M}=2.60)$, unlike those who never attended the festival $(\mathrm{M}=3.48) ;(\mathrm{t}=2.330 ; \mathrm{df}=58$; Sig.=0.023).

Concerning the aforementioned results we can conclude that the views and attitudes of the 'experts' who attended the festival are similar to the attitudes of 'regular' attendees, and that they highly appreciate the setting of the Fortress as a significant element in the attractiveness of the festival.

With regard to the third part of the questionnaire in which the possibility was offered to the respondents to comment on the Fortress as the EXIT festival venue, only $40 \%$ of the respondents commented $(\mathrm{N}=24)$. Most of the comments $(\mathrm{N}=2 \mathrm{I})$ were supportive for the festival to continue being staged at the Fortress with the highlighted responsibility for the organisers to protect the Fortress from being damaged at the time and after the festival by all means. At the same time substantial number of comments $(\mathrm{N}=\mathrm{I} 8)$ referred to legal regulations of financial support that the organisers should pay to funds for protection and revitalisation of the Fortress upon the completion of the festival every year. Only several comments $(\mathrm{N}=3)(\mathrm{I} 2.5 \%)$ expressed negative attitudes towards both the Fortress as the festival venue and the festival itself as a social phenomenon. 


\section{Comparison of the attitudes of the 'regular' attendees and 'experts'}

In this research, the same four attitudes were the subject of evaluation of 'regular' attendees (Besermenji et al., 2009) and 'experts'. This was done in order to determine the points of agreement and the most significant differences in the perception of the role of the Fortress as an element of attractiveness of the festival. These findings could help in bringing together the attitudes and views of these two groups, which will hopefully enhance the festival without endangering the interests of any group.

Table 2. The agreement with the attitudes by attendees [tourists] and 'experts'

\begin{tabular}{|l|l|r|r|r|r|}
\hline \multicolumn{2}{|c|}{} & Item 1 & Item 2 & Item 3 & Item 4 \\
\hline \multirow{3}{*}{ "Experts" } & Mean & 3.10 & 4.28 & 3.22 & 2.97 \\
\cline { 2 - 6 } & $\mathrm{N}$ & 60 & 60 & 60 & 60 \\
\cline { 2 - 6 } & Std. Dev. & 1.504 & 1.195 & 1.541 & 1.495 \\
\hline \multirow{4}{*}{ Tourists } & Mean & 4.64 & 4.61 & 1.71 & 1.98 \\
\cline { 2 - 6 } & $\mathrm{N}$ & 251 & 251 & 251 & 251 \\
\cline { 2 - 6 } & Std. Dev. & .785 & .669 & 1.214 & 1.210 \\
\hline \multirow{3}{*}{ Total } & Mean & 4.34 & 4.55 & 2.00 & 2.17 \\
\cline { 2 - 6 } & $\mathrm{N}$ & 311 & 311 & 311 & 311 \\
\cline { 2 - 6 } & Std. Dev. & 1.139 & .805 & 1.413 & 1.326 \\
\hline
\end{tabular}

As presented in Table 2 tourists displayed more extreme attitudes concerning the agreement statements (either they strongly agree or strongly disagree). This is why the standard deviation is smaller for all the statements in this group.

These differences have proven to be statistically significant by the application of the t-test: for ITEM I (t=-II,093; df=309; Sig.=0,00o); for ITEM $2(\mathrm{t}=-2,85 \mathrm{I} ; \mathrm{df}=309$; Sig.=0,005); ITEM $3(\mathrm{t}=8,200$; $\mathrm{df}=309$; Sig.=0,000); for ITEM $4(\mathrm{t}=-5,43 \mathrm{I} ; \mathrm{df}=309$; Sig. $=0,000)$.

As presented in the table, the evaluation of the expressed statements is the closest in the second statement, which refers to the appreciation of the setting of the Fortress providing a special experience for the visitors. Based on these results, we can conclude that the setting of the Fortress was valued as the most important element of attendees' satisfaction, and that both attendees and experts recognize the setting of the Fortress as a specific element providing special experience for the visitors. Although the attitudes to special setting of the Fortress are more or less similar for both groups of respondents, the largest dissimilarities are perceived in ATTITUDE I and ATTITUDE 3. The attendees in former researches (Besermenji et al., 2009) replied that the Fortress is an excellent venue for the festival and that they do not wish the festival to be relocated, whereas the experts expressed indecisiveness to those questions. The future actions to be undertaken should lead to convergence of attitudes followed with mutual understanding between the groups.

This finding is important for the organisers of the festival as well as for the experts as the starting point for further enhancement of the festival. Perhaps the festival should not be relocated, because this would deprive visitors of gaining the special satisfaction and experience. In the future, the ways of keeping the festival at the Fortress should be considered and at the same time the preservation of the Fortress and enhancement of it as a cultural monument and a special tourist attraction. Probably, one of the solutions is a constructive criticism the experts expressed in this research, which addresses to redirection of the part of the organisers' profit to projects for protection and restoration of the Fortress in which the organisers may cooperate with the experts from the Institute for Protection of Cultural Monuments. Moreover, in order to achieve convergence of positions between attendees and experts, it would be useful to constantly remind visitors of the significance of the Fortress as a cultural monument. Such messages might be conveyed to attendees through brochures or leaflets of the festival and during the festival, on the spot, through various activites intended to inform the visitors about the cultural importance of the Fortress, or even the inclusion of the visitors in protection measures for the Fortress at the time and after the festival. Nevertheless, these are some of the suggestions, which give organisers of the festivals and experts the choice to accept them and find mutual interest and determination to implement them.

\section{Conclusion}

In the paper, the sample of sixty experts, employed in the Institute for the Protection of Cultural Heritage of Vojvodina, the Institute for the Protection of Cultural Heritage of Novi Sad and travel agencies in Novi Sad, is used for conducting a questionnaire research. The sample includes 35 of those who attended the EXIT festival and 25 of those who never attended the EXIT festival. On average, the experts agree to a large extent with the attitude that the setting of the Petrovaradin Fortress contributes to the special experience of the attendees of the festival. However, it needs to be emphasized that among the experts there are significant differences in agreement with the given attitudes on the basis of the fact whether they attended the festival or not. The attitude that the Petrovaradin Fortress is an excellent venue for the 
organisation of the EXIT festival is more agreed upon by those who attended the festival, whereas the experts who did not visit the EXIT festival agree with the attitude to a lesser extent.

With reference to the attitude of relocating the EXIT festival from the Petrovaradin Fortress, it is more agreed upon, on average, by the experts who did not visit the festival, whereas those who attended it agree with the idea to a lesser extent. The experts who attended the EXIT festival also agree to a large extent that the EXIT festival would be equally attractive if organized at a different venue.

Indisputably, the EXIT festival has enormous cultural and also economic significance for Novi Sad. In case experts would agree upon this statement, it might contribute to obtaining practical solutions to continue staging the festival at the Fortress, to ensure higher protection for the Fortress at the same time and make efforts that the Fortress joins UNESCO World Heritage List. Any solutions for the future should take into account both the opinions and attitudes of attendees who are inseparable part of the festival.

Having observed the obtained results and the questionnaire research among the experts employed in institutions concerned with the protection of cultural monuments and the employees in travel agencies, it can be concluded that the authentic setting of the Petrovaradin Fortress contributes to the greater attractiveness of the EXIT festival.

\section{References}

Baum, T., Hagen, L. I999. Responses to seasonality. The experiences of peripheral destination. International journal of tourism research I, 299-3I2.

Besermenji, S., Pivac, T., Wallrabenstein, K. 2009. Significance of Authentic Ambience of The Petrovaradin Fortress on the Attractiveness of EXIT Festival. Geographica Pannonica I3, 2, 66-74.

Chang, J. 2005. Segmentation tourists to aboriginal cultural festivals: An example in the Rukai tribal area, Taiwan. Tourism Management 27, I224-I234.

Crompton, J.L., Lee, S., Shuster, T.J. 20oI. A guide for undertaking economic impact studies: the springfest example. Journal of Travel Research 40, I, 79-87.

Felsenstein, D., Fleischer, A. 2003. Local festivals and tourism promotion: The role of public assistance and visitor expenditure. Journal of Travel Research 4I, 4, 385-392

Fredline, E., Faulkner, B. 200o. Host community reaction: A cluster analysis. Annals of Tourism Research 27, 3, 763-784.
Getz, D. I997. Events management and Event Tourism. Cognizant Communications Corporation, New York.

Getz, D. 2007. Event tourism: Definition, evolution and research. Tourism Management 30, I-I6.

Gursay, D., Kim, K., Uysal, M. 2004. Percived impacts of festivals and special events by organisers: An extension and validation. Tourism Management 25, 2, I7I-I8I.

Jeong, G.H., Faulkner, B. I996. Resident perceptions of mega-event impacts: The Taejon international exposition case. Festival Management \& Event Tourism 4, I, 3-II.

Lee, C.K. 200o. A comparative study of Caucasian and Asian visitors to a Cultural Expo in an Asian setting. Tourism Management 25, 2, I69I76.

Lee, C.K., Lee. Y.K., Wicks, B.E. 2004. Segmentation of festival motivation by nationality and satisfaction. Tourism Management 25, 6I-70.

Markovic, Z. I996. Walking at the Petrovaradin Fortress. Tourist organization of Novi Sad, Novi Sad. (in Serbian)

Pivac, T., Kovačević, D., Garača, V. 2007. The role of the music festival Exit on the social and cultural life in the Balkanregion in the postwar period. The $8^{\text {th }}$ International Joint World Cultural Tourism Conference 2007. Busan, S.Korea, 217-222.

Romelić, J. 2006. Definition and classification of tourist events as a basis for creating manifestacionog tourism approach. Organization and development of tourism industry in the region of northeastern Bosnia and Herzegovina Bosnia. Proceedings. Tourist Board of the Tuzla Canton, Tuzla. (In Serbian)

Stanislav, F. 2004. Behavior Research Methods. Center for Applied Psychology. Belgrade. (In Serbian)

Stokes, R. 2008. Tourism strategy making: Insight to the events tourism domain. Tourism Management 29, 252-262.

Hadzic, O. 2005. Cultural tourism. Faculty of Natural Sciences and Mathematics, Department of Geography, Tourism and Hotel Management. Novi Sad, 353 pp (in Serbian)

Hamovic, J. I963. Festivals and their place in our cultural life. Journal "Cultural life", vol. 6,7. Festivali i njihovo mesto $\mathrm{u}$ našem kulturnom životu. Časopis „Kulturni život“ broj 6-7, Cultural and Educational Council of Yugoslavia, Belgrade. (in Serbian)

Wager, J. I995. Developing a strategy for the Angkor World Heritage Site. Tourism Management I6, 7, 515-523. 